\title{
PEMODELAN GENERATOR YANG EFEKTIF YANG DIPASANGKAN DENGAN IMPACT WRENCH SEBAGAIUSAHA UNTUK MENINGKATKAN DAYA PADA PEMBANGKIT LISTRIK TENAGA SAMPAH
}

\author{
Hubertus Ngaderman* dan Ego Srivajawaty Sinaga \\ Jurusan Fisika, Universitas Cenderawasih JayapuraJl. Kampwolker perumnas 3, Jayapura 99351, Indonesia \\ *e-mail: ngadermanh@gmail.com
}

\begin{abstract}
ABSTRAK
Sampah bisa dimanfaatkan menjadi sumber energi alternatif karena sampah adalah suatu bagian dari biomassa. Riset ini akan terfokus pada model numerik Pembangkit Listrik Tenaga Sampah. Peneliti menggantikan turbin dengan impact dengan spesifikasi tekanan tertentu, impact memutar generator. Penerobosan terbaru yang dilakukan peneliti yaitu menggantikan turbin dengan impact. Tujuan penelitian ini untuk mendapatkan tegangan rms dari suatu generator, dimana generator tersebut adalah generator yang mampu menyuplai tegangan rms $12 \mathrm{~V}$ Upaya ini dilakukan untuk mengkonversikan energi sampah menjadi energi listrik. Metode di dalam penelitian ini adalah model numerik dan software yang digunakan visual basic application (VBA). Besar energi yang masuk dari boiler ke dalam impact telah dihitung dan nilainya adalah di dalam range dimana impact dapat menampung Jika suhu $276^{\circ} \mathrm{c}, 12 \mathrm{~V}$, maka rotor akan berputar dengan kecepatan $497 \mathrm{rpm}$. Untuk massa air $300 \mathrm{gr}$, suhu $82^{\circ} \mathrm{C}$ maka kecepatan sinkronous rotor $124 \mathrm{rpm}$, tegangan rms $3 \mathrm{~V}$. Jika suhu $230{ }^{\circ} \mathrm{C}, 12 \mathrm{~V}$, maka rotor akan berputar dengan kecepatan $497 \mathrm{rpm}$. Untuk mencapai tegangan rms $12 \mathrm{~V}$ maka rotor pada generator harus berputar pada kecepatan sinkronous $497 \mathrm{rpm}$.
\end{abstract}

Kata kunci: Sampah; Suhu; Tegangan rms; Rotor; Kecepatan sinkronous

\section{ABSTRACT}

[Modeling Generator Which Effectively Be Paired on Impact Wrench As An Effort To Increasing Power in Waste Power Plant] Waste can be used as an alternative energy source because waste is a part of biomass. This research will focus on the numerical model of the waste power plant. Researcher replace the turbine with an impact with a certain pressure specification, the impact rotates the generator. The latest breakthrough made by researchers is replacing turbines with impact. The purpose of this study is to obtain an rms Voltage from a generator, where the generator is a generator capable of supplying a $12 \mathrm{~V}$ rms voltage. This effort was made to convert waste energy into electrical energy. The method in this research is numerical model and software used is visual basic application (VBA). The amount of energy that enters from the boiler into the impact has been calculated and the value is within the range where the impact can accommodate, if the temperature is $276{ }^{\circ} \mathrm{C}, 12 \mathrm{~V}$, then the rotor will rotate at a speed of $497 \mathrm{rpm}$. For a mass of $300 \mathrm{gr}$ of water, a temperature ofb $820^{\circ} \mathrm{C}$, the rotor synchronous speed is $124 \mathrm{rpm}$, the rms voltage is $3 \mathrm{~V}$. If the temperature is $230{ }^{\circ} \mathrm{C}, 12 \mathrm{~V}$, the rotor will rotate at a speed of $497 \mathrm{rpm}$. To achieve an rms voltage of $12 \mathrm{~V}$, the rotor on the generator must rotate at a synchronous speed of $497 \mathrm{rpm}$.

Keywords: Waste; Temperature rms; Rotor; Synchronous speed

\section{PENDAHULUAN}

Sampah terdiri atas sampah organik dan anorganik (Nur et al, 2014). Banyak keuntungan yang didapatkan dari pengembangan pembangunan Pembangkit Listrik Biomassa sebagai sumber penghasil energi listrik yang berkepanjangan dan terus menerus dalam memenuhi kebutuhan manusia. Peluang untuk menghasilkan energi listrik di berbagai daerah karena bahan utamanya mudah didapatkan dan dapat juga membuat lapangan pekerjaan bagi masyarakat setempat sebagai wujud wacana pemerintah untuk memberikan lapangan pekerjaan dan mengurangi pengangguran (Isarani, 2015). Sama seperti halnya dengan biomassa maka sampah juga bisa dimanfaatkan menjadi sumber energi alternatif karena sampah adalah suatu bagian dari biomassa. Sampah merupakan masalah klasik yang tak pernah habis untuk dibahas. Memanfaatkan sampah sebagai energi listrik telah dilakukan Korea Selatan dengan kapasitas 50 megawatt di Incheon. PLTSa itu mampu menyuplai kebutuhan energi listrik lebih dari 180 ribu rumah tangga serta mengurangi impor minyak hingga 500 ribu barel per tahun (Biyan et al, 2015). National Urban Development Strategy (NUDS). menunjukan rata-rata buangan sampah per penduduk kota adalah $0,5 \mathrm{~kg} / \mathrm{hari}$, dengan mengalikan data jumlah penduduk kota maka dapat diketahui perkiraan potensi sampah kota. Secara umum sampah kota terdiri dari $75 \%$ sampah organik dan sisanya 
sampah anorganik (Didik et al, 2011). Salah satu masalah utama perkotaan adalah tata kelola sampah yang masih membutuhkan perhatian besar, khususnya pengelolaan sampah plastik yang sulit terurai. Jakarta dengan penduduk lebih dari 9 juta jiwa, jumlah sampah plastik yang ditimbun dapat mencapai 400 ton. Untuk mengatasi jumlah sampah plastik tersebut diperlukan usaha menguranginya (Monice et al, 2016).

Perpindahan kalor dari incinerator ke boiler akan membentuk uap air panas bertekanan tinggi (Soelaiman, 2000). Limbah pertanian dan hutan merupakan sampah organik yang dikategorikan sebagai biomassa (Wahyudi, 2006). Impact memutar generator, di dalam generator tersendiri terdapat magnet permanen (Hari et al, 2012). Informasi nilai kalor sampah yang masuk ke dalam PLTSa 2500 $\mathrm{kkal} / \mathrm{kg}$ dengan kadar air 30\% (Monice, 2013). Penggunaan air sebagai fluida karena alasan ekonomis yaitu murah dan mudah didapat (Eflita et al, 2017, Muhammad et al, 2015). Impact memutar generator, di dalam generator tersendiri terdapat magnet permanen (Wahyudi et al, 2015, Jefri et al, 2017). Kapasitas turbin dan generator (Monice et al, 2016). Impact memutar generator, di dalam generator tersendiri terdapat magnet permanen (Jefri et al, 2017). Daerah yang masih mengalami kekurangan daya listrik seperti Papua masih menggunakan bahan bakar minyak (Salmawaty et al, 2017). PLTSa merupakan pembangkit listrik yang memanfaatkan sampah sebagai bahan bakar (Nur, 2017). Konduksi berubah menjadi konveksi dimana terjadi perpindahan zat perantara (Arwizet, 2017). Penggunaan air sebagai fluida karena alasan ekonomis yaitu murah dan mudah didapat (Eflita, 2017). Penelitian penulis berada disini yaitu memodelkan suhu dimana berkaitan dengan efisiensi pembangkit listrik tenaga sampah dengan menggunakan impact wrench sebagai pengganti turbin (Ngaderman $\mathrm{H}$, Sinaga S, 2020)

Riset ini akan terfokus pada model numerik PLTSa dengan menggunakan visual basic application. Parameter input dan variabel terhitung yang berperan untuk mendapatkan output akhir yaitu tegangan listrik rms. Peneliti menggantikan turbin dengan impact dengan spesifikasi tekanan $6.10^{5} \mathrm{~N} / \mathrm{m}^{2}$, kecepatan maksimum $7000 \mathrm{rpm}$, torka maksimum 500 $\mathrm{Nm}$ dan energy maksimal 366.519 joule. Impact memutar generator, di dalam generator tersendiri terdapat magnet permanen (Wahyudi et al, 2015). Suatu penerobosan terbaru peneliti menggantikan turbin dengan impact. Besar energi yang masuk dari boiler ke dalam impact tersebut telah dihitung dan nilainya adalah di dalam range tersebut (Ngaderman H, 2020).
Tujuan penelitian ini untuk mendapatkan tegangan rms dari suatu generator, dimana generator tersebut adalah generator yang mampu menyuplai tegangan rms $12 \mathrm{~V}$. Upaya ini dilakukan untuk mengkonversikan energi sampah menjadi energi listrik. Alasan penelitian ini menggunakan generator tegangan rms $12 \mathrm{~V}$ dikarenakan di dalam skala rumahan maka suplai listrik yang dibutuhkan juga tidak terlalu besar. Generator yang menjadi topik utama di dalam penelitian ini adalah generator sinkron dan generator magnet permanen. Perbedaan diantara kedua generator ini hanyalah pada rotor. Tujuan akhir dari penelitian ini adalah mendapatkan tegangan rms.Penelitian ini diharapkan bermanfaat sebagai acuan dalam pengembangan ilmu pengetahuan pada bidang Fisika di dalam upaya meningkatkan performansi konversi energi gerak (pembakaran sampah yang masuk ke turbin) menjadi listrik. Manfaat utama dari hasil penelitian ini adalah pemodelanPLTSa tipe insinerasi yang menjadi acuan untuk pengembangan PLTSa skala pabrikan. Harapanselanjutnyaadalah pembuatan prototype PLTSa tipe incinerator.

\section{METODE}

Metode di dalam penelitian ini adalah model numerik dengan menggunakan komputer sebagai alat bantu hitung (komputasi) untuk menyelesaikan perhitungan dan software yang digunakan adalah Visual Basic Application (VBA). Terdapat dua parameter input yang berperan yaitu parameter yang bernilai konstan seperti kalor jenis air $(4200 \mathrm{~J} / \mathrm{kgK})$, massa jenis air $\left(1000 \mathrm{~kg} / \mathrm{m}^{3}\right)$, suhu awal $0{ }^{0} \mathrm{C}$, tekanan maksimum yang mampu dimiliki boiler $\left(8,34 \times 10^{5} \mathrm{~N} / \mathrm{m}^{2}\right)$ dan torka $(500 \mathrm{Nm})$. Parameter input yang bernilai tidak konstan dan bisa diinput berdasarkan tujuan penelitian ini adalah massa air sampel $1(0,25 \mathrm{~kg})$, massa air sampel $2(0,3 \mathrm{~kg})$, massa air sampel $1(0,25 \mathrm{~kg})$, massa air sampel $3(0,4$ $\mathrm{kg})$, volume akhir air sampel $4\left(0,5 \times 10^{-4} \mathrm{~m}^{3}\right)$, suhu akhir air bervariasi mulai dari $80{ }^{0} \mathrm{C}$ sampai dengan $150{ }^{\circ} \mathrm{C}$, jumlah kutub atau jumlah kumparan (12), jumlah lilitan per kumparan (63), besar fluks magnet $2,17 \cdot 10^{-4} \mathrm{~Wb}$. Variabel terhitungannya adalah meliputi volume, perubahan suhu dan kerja, kecepatan sinkronous, frekuensi dan output akhir yang menjadi inti dari penelitian ini yaitu tegangan listrik rms. Hubungan antara kecepatan sudut $(\omega)$ dan torka impact dengan kerja, energi atau daya adalah

$$
W=\tau \times \omega
$$

Perubahan volume pada saat pemanasan dari incinerator akan dikaji di dalam perhitungan untuk mendapatkan suhu yang dicari, suhu tersebut adalah suhu yang ditetapkan untuk mencapai kerja 40.000 joule. Diandaikan bahwa air dengan massa 
awalnya $250 \mathrm{gr}$ dan volume awalnya adalah $5.10^{-5} \mathrm{~m}^{3}$ akan mengembang sampai dengan memenuhi ruang dengan volume akhirnya $5.10^{-2} \mathrm{~m}^{3}$. Dengan memasukkan massa air (sampel 1) $2,5 \cdot 10^{-1} \mathrm{~kg}$, kalor jenis air $4200 \mathrm{~J} / \mathrm{kgK}$ maka kerja ekspansi luar didapatkan $4,15.10^{4} \mathrm{~J}$ lihat persamaan 2

$$
W=P\left(V_{v}-V_{l}\right)
$$

Suhu mula-mula $0^{\circ} \mathrm{C}$ akan meningkat sampai dengan suhu yang dicari. Dengan memasukkan massa air (sampel 1), kalor jenis air, kerja ekspansi luar maka didapatkan variable suhu.

Simbol $\omega$ digantikan dengan $N_{s}$ dan $\Phi$ adalah flux tiap kutub di dalam satuan $W b . P$ adalah jumlah kutub, $N_{s}$ adalah kecepatan sinkronous ( $r p m$ ) dan $f$ adalah frekuensi induksi di dalam satuan $\mathrm{Hz}$. Asumsikan lilitan terkonsentrasi, anggaplah satu konduktor ditempatkan di dalam satu slot . Menuruti hukum induksi elektromagnet Faraday

$$
e_{\text {ave }}=\frac{d \phi}{d t}
$$

maka nilai rata-rata induksi emf $e_{\text {ave }}$ per konduktor di dalam satu revolusi dari sebuah konduktor

$$
\mathrm{e}_{\mathrm{ave}} \text { per konduktor }=\frac{\Phi P \mathrm{~N}_{\mathrm{s}}}{60}
$$

Sehingga didapatkan pers tegangan emf

$$
\mathrm{E}_{\mathrm{ph}}=4,44 \phi f \mathrm{~T}_{\mathrm{ph}}
$$

Formulasi yang lebih spesifik adalah diturunkan dari pers (5). Pers itu menjadi lebih familiar untuk menghitung tegangan rms dimana parameter masukkan dapat diambil dari data sheet generator yang dibeli. Selain dibeli juga dapat dimodifikasi sesuai dengan tujuan peneliti di dalam rangka untuk memperbesar tegangan rms-nya. Adapun generator yang dipakai untuk pemodelan ini adalah generator magnet permanendengan spesifikasi sebagai berikut: (1) Jumlah lilitan per kumparan 63 buah. (2) Fluks magnet $2,17 \cdot 10^{-4} \mathrm{~Wb}$. (3) Jumlah kumparan 12 (4) Jumlah fase 3 buah. Sebagai contoh tegangan rms untuk massa sampel 1 , ditulis

$$
\varepsilon_{m s}\left(m_{1}\right)=4,44 . N \cdot f_{m_{1}} \cdot \phi_{m a k s} \frac{N_{s}}{N_{p h}}
$$

Tegangan rms untuk massa sampel 2, ditulis

$$
\varepsilon_{m s}\left(m_{2}\right)=4,44 . N \cdot f_{m_{2}} \cdot \phi_{m a k s} \cdot \frac{N_{s}}{N_{p h}}
$$

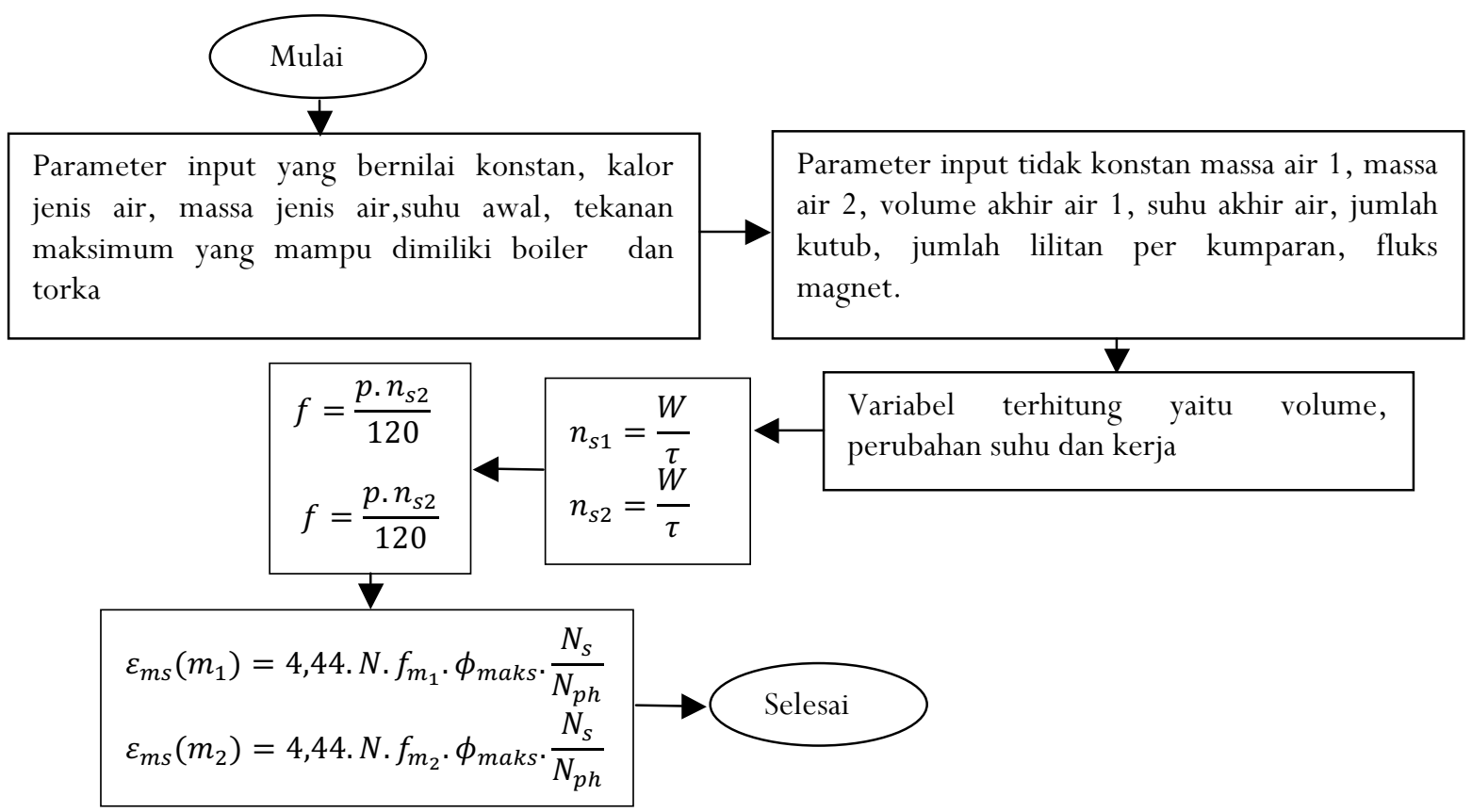

Gambar 1. Diagram alir generator AC untuk mendapatkan tegangan RMS 


\section{HASIL DAN PEMBAHASAN}

Peneliti membuat model numerik di dalam bentuk program yang dicetak pada software visual basic application (VBA) dan didapatkan hasil sebagai berikut.

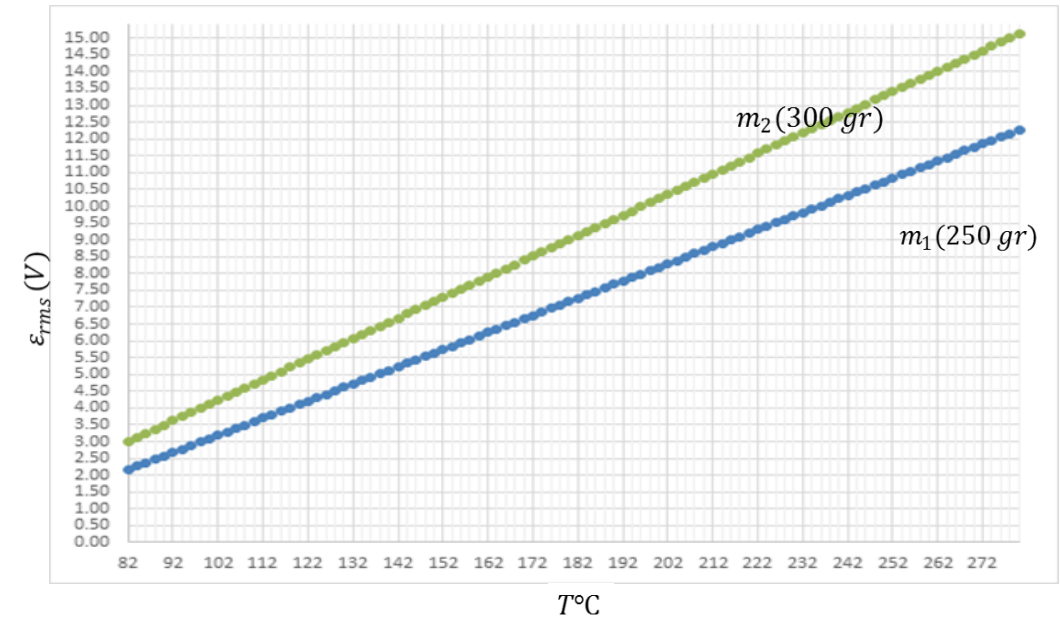

Gambar 2. Grafik tegangan rms vs suhu untuk massa air yang ditampung di dalam boiler dengan massa masing-masing $m_{1}(250 \mathrm{gr})$ dan $m_{2}(300 \mathrm{gr})$.

Pada Gambar 2 terlihat bahwa pada suhu $82^{\circ} \mathrm{C}$ tegangan rms akan bernilai $2,17 \mathrm{~V}$ untuk air yang ditampung di dalam boiler dengan massa $m_{1}(250 \mathrm{gr})$. Di dalam rangka mencapai tegangan rms $12 \mathrm{~V}$ maka suhu yang dibutuhkan adalah $276^{\circ} \mathrm{C}$ dan suhu tersebut meningkat sampai dengan jumlah yang tak terbatas. Dalam pemodelan ini peneliti hanya membatasi nilai sampai dengan $180^{\circ} \mathrm{Cdikarenakan}$ sampah yang digunakan sebagai sumber pembakaran tidak banyak andaikan suhunya 300 derajat maka sampah yang digunakan akan banyak dan dengan demikian menjadi tidak efektif . Air dengan massa $m_{1}(250 \mathrm{gr})$ akan memberikan tegangan yang dibutuhkan pada suhu $276^{\circ} \mathrm{C}$. Terlihat juga bahwa pada suhu $82^{\circ} \mathrm{C}$ tegangan rms bernilai $3 \mathrm{~V}$, air yang ditampung di dalam boiler dengan massa $m_{2}$ (300gr)tegangan rms $12 \mathrm{~V}$ maka suhu yang dibutuhkan adalah $230^{\circ} \mathrm{C}$ dan suhu tersebut meningkat sampai dengan jumlah yang tak terbatas.

Pada Gambar 3 terlihat bahwa pada suhu $82^{\circ}$ Ctegangan rms akan bernilai 4,68 V untuk air yang ditampung di dalam boiler dengan massa $m_{3}(400 \mathrm{gr})$. Di dalam rangka mencapai tegangan rms $12 \mathrm{~V}$ maka suhu yang dibutuhkan adalah $172^{\circ} \mathrm{C}$ dan suhu tersebut akan terus meningkat. Terlihat juga bahwa pada suhu $82^{\circ} \mathrm{C}$ tegangan rms bernilai $6,36 \mathrm{~V}$ air yang ditampung di dalam boiler dengan massa $m_{4}(500 \mathrm{gr})$. Di dalam rangka mencapai tegangan rms $12 \mathrm{~V}$ maka suhu yang dibutuhkan adalah $138^{\circ} \mathrm{C}$ dan suhu tersebut terus meningkat.

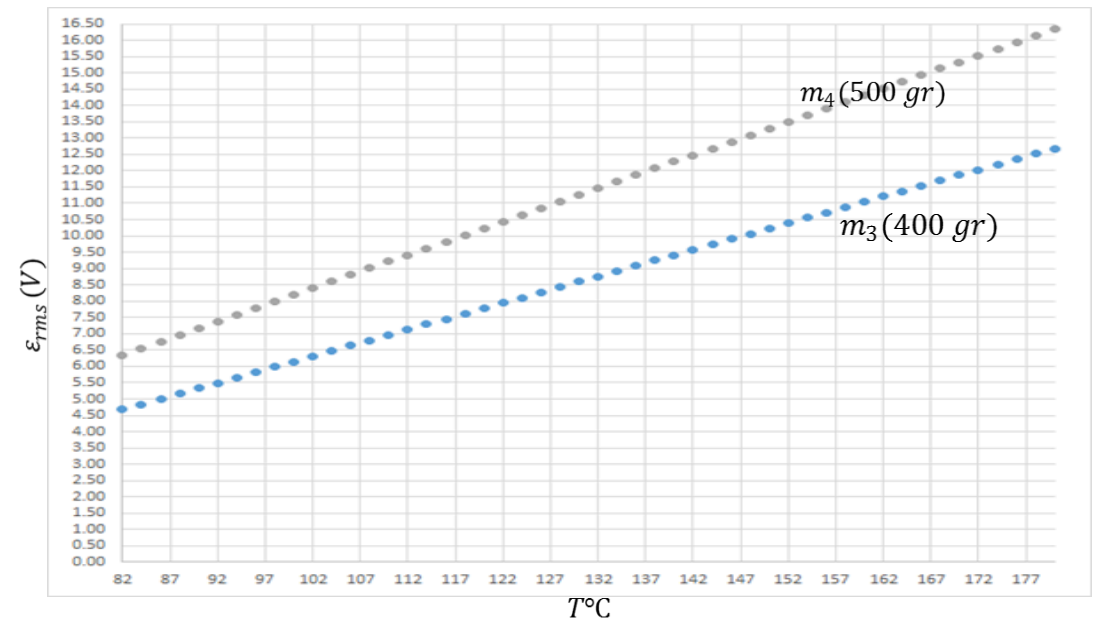

Gambar 3. Grafik tegangan rms vs suhu untuk massa air yang ditampung di dalam boiler dengan massa masing-masing $m_{3}(400 \mathrm{gr})$ dan $m_{4}(500 \mathrm{gr})$. 
Massa air $m_{1}$ yang ditampung di dalam boiler dimana massa air tersebut adalah $250 \mathrm{gr}$, pada saat dipanaskan sampai dengan suhu $82^{\circ} \mathrm{C}$ maka rotor pada generator akan berputar dengan kecepatan sinkronous $89 \mathrm{rpm}$, tegangan rms yang dihasilkan adalah 2,17 V. Jika dipanaskan sampai dengan suhu $276^{\circ} \mathrm{C}$ dimana tegangan rms itu adalah $12 \mathrm{~V}$ maka rotor pada generator akan berputar dengan kecepatan sinkronous $497 \mathrm{rpm}$ Untuk massa air $m_{2}$ yang ditampung di dalam boiler dimana massa air tersebut adalah $300 \mathrm{gr}$, pada saat dipanaskan sampai dengan suhu $82^{\circ} \mathrm{C}$ maka rotor pada generator akan berputar dengan kecepatansinkronous $124 \mathrm{rpm}$,
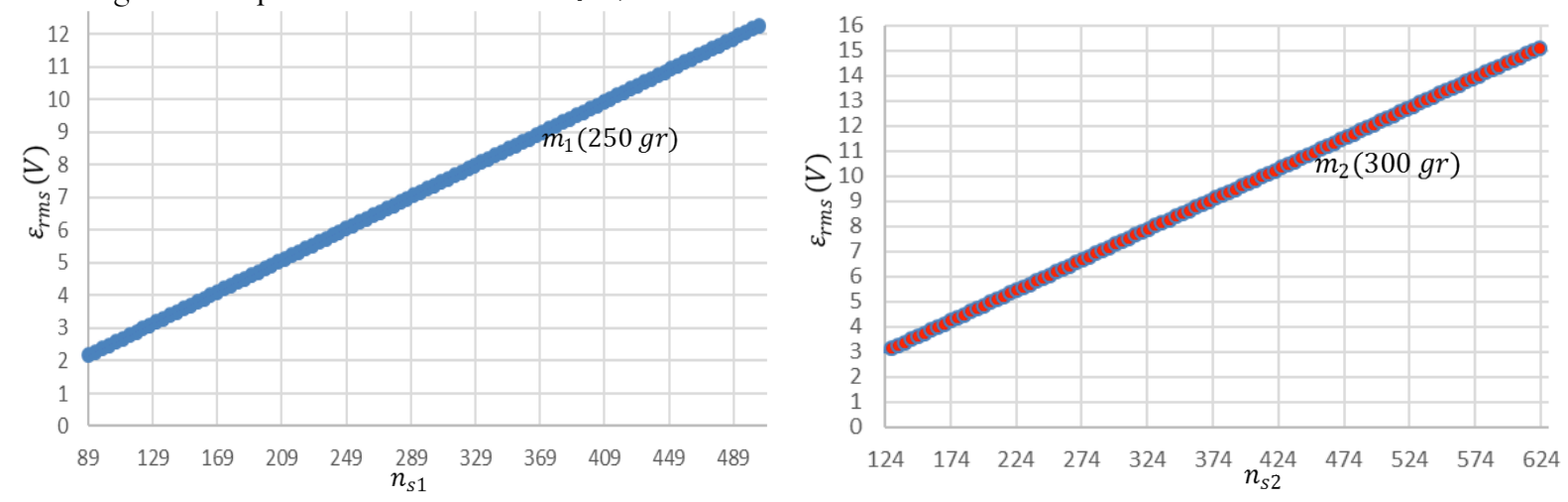

tegangan rms yang dihasilkan adalah $3 \mathrm{~V}$. Jika dipanaskan sampai dengan suhu $230^{\circ} \mathrm{C}$ dimana tegangan $\mathrm{rms}$ itu adalah $12 \mathrm{~V}$ maka rotor pada generator akan berputar dengan kecepatan sinkronous $497 \mathrm{rpm}$. Untuk mencapai tegangan rms $12 \mathrm{~V}$ maka rotor pada generator harus berputar pada kecepatan sinkronous $497 \mathrm{rpm}$. Berdasarkan uraian diatas maka diperoleh grafik hubungan tegangan rms (volt) vs kecepatan sinkronous (rpm) pada Gambar 4 dan untuk grafik kecepatan sinkronous (rpm) vs suhu dapat dilihat pada gambar 5 . ditampung di dalam boiler dengan massa masing-masing $m_{1}(250 \mathrm{gr})$ dan $m_{2}(300 \mathrm{gr})$.

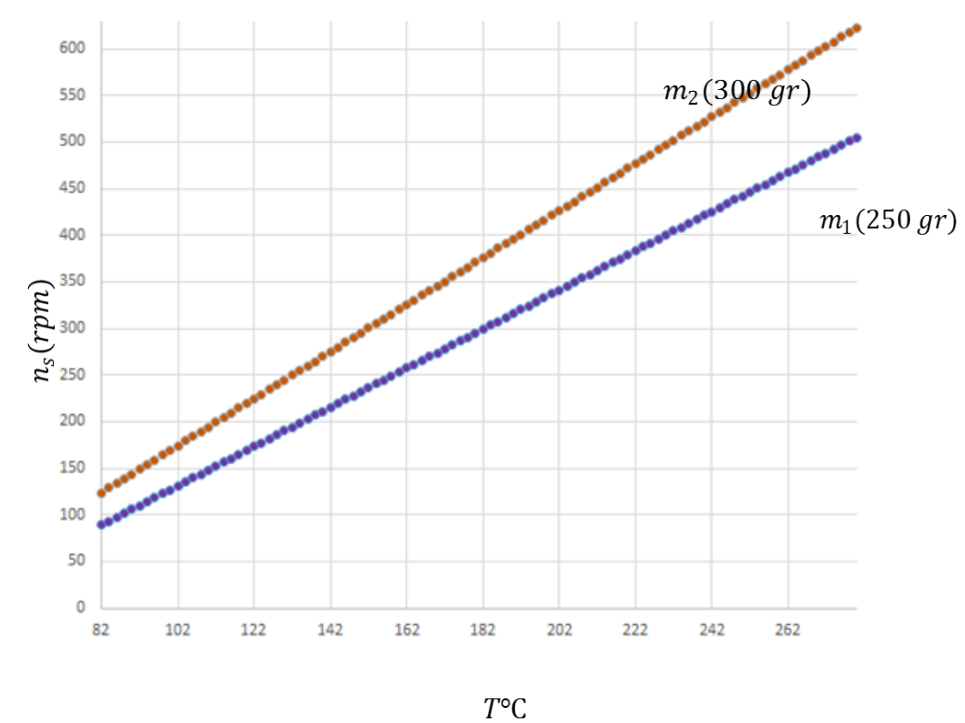

Gambar 5. Grafik kecepatan sinkronous (rpm) vs suhu untuk massa air yang ditampung di dalam boiler dengan massa masing-masing $m_{1}(250 \mathrm{gr})$ dan $m_{2}(300 \mathrm{gr})$.

\section{KESIMPULAN}

Air dengan massa 250gr memerlukan suhu sebesar $276^{\circ} \mathrm{C}$ untuk memberikan tegangan yang dibutuhkan sedangkan air dengan massa $300 \mathrm{gr}$, suhunya adalah $230^{\circ} \mathrm{C}$, selisih suhu sebesar $46^{\circ} \mathrm{C}$. Air dengan massa $400 \mathrm{gr}$ memerlukan suhu sebesar $172^{\circ} \mathrm{C}$ untuk memberikan tegangan yang dibutuhkan sedangkan air dengan massa $500 \mathrm{gr}$, suhunya adalah $138^{\circ} \mathrm{C}$, selisih suhu sebesar $34^{\circ} \mathrm{C}$. Untuk massa air
$250 \mathrm{gr}$, suhu $82^{\circ} \mathrm{C}$ maka kecepatan sinkronous rotor $89 \mathrm{rpm}$, tegangan rms $2,17 \mathrm{~V}$. Jika suhu $276^{\circ} \mathrm{C}, 12 \mathrm{~V}$, maka rotor akan berputar dengan kecepatan $497 \mathrm{rpm}$. Untuk massa air $300 \mathrm{gr}$, suhu $82^{\circ} \mathrm{C}$ maka kecepatan sinkronous rotor $124 \mathrm{rpm}$, tegangan rms $3 \mathrm{~V}$. Jika suhu $230^{\circ} \mathrm{C}, 12 \mathrm{~V}$, maka rotor akan berputar dengan kecepatan $497 \mathrm{rpm}$. Untuk mencapai tegangan rms $12 \mathrm{~V}$ maka rotor pada generator harus berputar pada kecepatan sinkronous $497 \mathrm{rpm}$. 


\section{SARAN}

Diperlukan generator magnet permanen dengan spesifikasi sebagai berikut: (1) Jumlah lilitan per kumparan 63 buah. (2) Fluks magnet $2,17 \cdot 10^{-4} W b$. (3) Jumlah kumparan 12. (4) Jumlah fase 3 buah, untuk menjawab penelitian ini karena sifat penelitian ini hanyalah model numerik. Untuk pengembangan ontologi penelitian baik berupa epistomologi dan eksperimen pikiran maka model numerik dapat direkayasa dengan melibatkan beberapa parameter input dan variabel yang berkorespondensi. Untuk mendapatkan tegangan listrik rms12 $V$ dengan kecepatan sinkronous $N_{s}$ yang rendah maka parameter dan variabel input dapat direkayasa. Parameter input ini meliputi (massa, volume dan suhu) air, jumlah kutub $P$, jumlah lilitan dan fluks magnet $\Phi$. Variabel input meliputikecepatan sinkronous dan $f$ frekuensi induksi. Variabel output adalah tegangan listrik rms.

\section{DAFTAR PUSTAKA}

Arwizet, 2017. Mesin Destilasi Pengolahan Sampah Plastik Menjadi Bahan Bakar Minyak Menggunakan Kondensor Bertingkat Dan Pendingin Kompresi Uap. Jurusan Teknik Mesin, Fakultas Teknik, Universitas Negeri Padang.

Biyan, Sarwoko, Ekki, 2015. Realisasi Pembangkit Listrik Mini Tenaga Sampah. JurusanTeknikElektro-_ FakultasTeknik Elektro- UniversitasTelkom

Didik, Gunawan, 2011. Studi Perencanaan Pembangkit Listrik Tenaga sampah Dengan teknologi dry anaerobic convertion. Universitas Islam Sultan Agung Semarang

Eflita Y, Revki R, 2017. Analisa Efisiensi Isentropik dan Exergy Destruction Pada Turbin Uap Sistem Pembangkit Listrik Tenaga Gas dan Uap. Departemen Teknik Mesin Fakultas Teknik Universitas Diponegoro.

Isarani, Ismail, Kho, 2015. Analisis Kinerja Pembangkit Listrik Tenaga Uap Biomassa Menggunakan Limbah Kayu. Fakultas Teknik Universitas Tanjungpura Pontianak

Haliday, 1986. Fisika Jilid Satu. Airlangga

Halliday, 1986. Fisika Jilid Dua. Airlangga

Hari, Ropiudin, Budi, 2012. Generator Magnet Permanen Sebagai Pembangkit Listrik Putaran Rendah. Teknik Elektro Unsoed.

Jefri, Adam, 2017. Pembangkit Listrik Tenaga Air Sungai Dengan Kombinasi Turbin Savonius dan Heliks

Leo, Mahdi, Syahrizal, 2016. Perancangan Prototype Generator Magnet Permanen 1
Fasa Jenis Fluks Aksial pada Putaran Rendah. Jurnal Online Teknik Elektro

Monice, Syafii, 2013. Operasi Ekonomis Pembangkit Listrik Tenaga Sampah (PLTSa) dan (PLTG) Dalam Melayani Beban Puncak Kelistrikan Sumbar. Teknik Elektro Universitas Andalas.

Monice, Perinov, 2016. Analisis Potensi Sampah Sebagai Bahan Baku Pembangkit Listrik Tenaga Sampah (PLTSa) Di Pekanbaru. Program Studi Teknik Elektro, Fakultas Teknik, Universitas Lancang Kuning. SainETIn (Jurnal Sain, Energi, Teknologi \& Industri), Vol. 1 No. 1, Desember 2016, pp. 9 - 16

Muhammad, Hary, Agung, 2015. Deteriorasi Kinerja Ketel Uap Takuma N1300 SA Terhadap Waktu Operasional pada Sistem Pengolahan Kelapa Sawit Dengan Kapasitas 90 Ton TBS/Jam. Teknik Mesin, Fakultas Teknologi Industri, Institut Sains dan Teknologi AKPRIND Yogyakarta

Nur A T, Rina M, 2017. Desain Pembangkit Listrik Tenaga Sampah (PLTSa) Menggunakan Teknologi Pembakaran Yang Fisibel Studi Kasus TPST Bantargebang

Rendra P, Suryadimal, Jovial M, 2012. Perancangan Sistim Pembangkit Tenaga Uap Mini Dengan Bahan Bakar Sampah. Jurusan Teknik Mesin, Fakultas Teknologi Industri, Universitas Bung Hatta, Padang

Safrizal, 2014. Distribusi Generasi Pembangkit Listrik Tenaga Sampah Kota (PLTSa) Tipe Incinerator Solusi Listrik Alternatif Kota Medan. Program Studi Teknik Elektro Fakultas Sains dan Teknologi Universitas Islam Nahdlatul Ulama (UNISNU) Jepara

Salmawaty T, Bambang, Ade, 2017, Yasin, 2017. Rancang Bangun Prototype Pembangkit Listrik Tenaga Sampah (PLTSa). Fakultas Teknik, Jurusan Teknik Elektro, Universitas Negeri Gorontalo

Soelaiman, 2000. Analisa Prestasi Kerja Turbin Uap Pada Beban Yang Bervariasi. Jurusan Mesin, Universitas Muhammadiyah Jakarta.

Ngaderman H, Srivajawaty, 2020. Pemodelan Suhu Dan Efisiensi Pembangkit Listrik Tenaga Sampah Dengan Menggunakan Impact Wrench Sebagai Pengganti Turbin. https: / /iopscience.iop.org/article/10.108 $\underline{8 / 1742-6596 / 1491 / 1 / 012015 / \mathrm{pdf}}$

Nugroho S, 2016. Desain Generator Magnet Permanen rpm Rendah Dengan Memanfaatkan Motor Kipas. Teknik Elektro Fakultas Teknik Universitas Muhammadiyah Surakarta 
Nur A T, Rina M, 2017. Desain Pembangkit Listrik Tenaga Sampah (PLTSa) Menggunakan Teknologi Pembakaran Yang Fisibel Studi Kasus TPST Bantargebang

Uray I F, 2016. Studi Potensi Limbah Kota Sebagai Pembangkit Listrik Tenaga Sampah (PLTSa) Kota Singkawang. Program Studi Teknik Elektro Jurusan Teknik Elektro Fakultas Teknik Universitas Tanjungpura Pontianak.

Vitri P, Toni, 2013. Analisis Kapasitas Produksi Uap Terhadap Stabilitas Putaran Mesin Turbin. Widya Teknika Vol.21 No.1; Maret 2013

Wahyudi, 2006. Penelitian Nilai Kalor Biomassa Perbandingan Antara Hasil

Pengujian
Dengan Hasil Perhitungan. Teknik Mesin Fakultas Teknik Universitas Muhammadiyah Yogyakarta.

Wahyudi, 2015. Perancangan Mini Generator Turbin Angin 200 W Untuk Energi Angin Kecepatan Rendah. Teknik Elektro, Fakultas Teknologi Industri, Universitas Islam Indonesia.

Yunus Y, Sihana, Subekti L, 2012. Modifikasi Alternator Mobil Menjadi Generator 3 Fasa 220 $V 600 \mathrm{rpm}$. STTN BATAN Teknofisika Nuklir dan FakultasTeknik Universitas Gadjah Mada. 